\title{
Ammonium-Dependent Shortening of CLS in Yeast Cells Starved for Essential Amino Acids Is Determined by the Specific Amino Acid Deprived, through Different Signaling Pathways
}

\author{
Júlia Santos, ${ }^{1,2}$ Cecília Leão, ${ }^{1,2}$ and Maria João Sousa ${ }^{3}$ \\ ${ }^{1}$ Life and Health Sciences Research Institute (ICVS), School of Health Sciences, University of Minho, 4710-057 Braga, Portugal \\ ${ }^{2}$ ICVS/3B's-PT Government Associate Laboratory, Braga/Guimarães, Portugal \\ ${ }^{3}$ Molecular and Environmental Biology Centre (CBMA), Department of Biology, University of Minho, 4710-057 Braga, Portugal
}

Correspondence should be addressed to Maria João Sousa; mjsousa@bio.uminho.pt

Received 16 May 2013; Revised 9 July 2013; Accepted 16 July 2013

Academic Editor: Sergio Giannattasio

Copyright (C) 2013 Júlia Santos et al. This is an open access article distributed under the Creative Commons Attribution License, which permits unrestricted use, distribution, and reproduction in any medium, provided the original work is properly cited.

\begin{abstract}
Ammonium $\left(\mathrm{NH}_{4}^{+}\right)$leads to chronological life span (CLS) shortening in Saccharomyces cerevisiae BY 4742 cells, particularly evident in cells starved for auxotrophy-complementing amino acids (leucine, lysine, and histidine) simultaneously. Here, we report that the effect of $\mathrm{NH}_{4}{ }^{+}$on aging yeast depends on the specific amino acid they are deprived of. Compared with no amino acid starvation, starvation for leucine alone or in combination with histidine resulted in the most pronounced $\mathrm{NH}_{4}{ }^{+}$-induced CLS shortening, whereas starvation for lysine, alone or in combination with histidine resulted in the least sensitivity to $\mathrm{NH}_{4}{ }^{+}$. We also show that $\mathrm{NH}_{4}{ }^{+}$-induced CLS shortening is mainly mediated by Torlp in cells starved for leucine or histidine but by Ras $2 \mathrm{p}$ in cells starved for lysine, and in nonstarved cells. Sch9p protected cells from the effect of $\mathrm{NH}_{4}{ }^{+}$under all conditions tested (starved or nonstarved cells), which was associated with Sch9p-dependent Hoglp phosphorylation. Our data show that $\mathrm{NH}_{4}^{+}$toxicity can be modulated through manipulation of the specific essential amino acid supplied to cells and of the conserved Ras2p, Torlp, and Sch9p regulators, thus providing new clues to the development of environmental interventions for CLS extension and to the identification of new therapeutic targets for diseases associated with hyperammonemia.
\end{abstract}

\section{Introduction}

In all living organisms, cell survival is mediated by metabolic regulation in response to environmental conditions. This regulation is conserved from yeasts to mammals and is mediated by complex nutrient signaling pathways that control the necessary metabolic changes that take place when environmental conditions change [1]. In yeast, when nutrients are depleted, cells undergo a growth arrest phase characterized by downregulation of growth signaling pathways and upregulation of several processes, such as accumulation of carbohydrates, autophagy, and stress resistance $[2,3]$. The length of time these nondividing yeast cells remain viable for is defined as the chronological life span (CLS) of the population [4]. The composition of the culture medium can modulate CLS, and therefore, culturing cells in different media leads to differences in CLS [5]. Manipulation of several single components of the culture medium is known to extend CLS, such as reducing glucose concentration (known as caloric restriction-CR) or manipulating the supply of amino acids [5-9]. Several studies in the literature report different effects of amino acids on life span regulation, depending on which amino acid is deprived [6-10]. In this context, it is known that starvation for nonessential amino acids (strains without auxotrophies) used as preferred nitrogen sources can extend CLS [11-13], while starvation for auxotrophycomplementing amino acids (essential amino acids) reduces CLS $[7,10]$. However, not all essential amino acids contribute equally to the effects on CLS. In fact, it has been described that leucine plays a more important role in CLS extension in auxotrophic strains $[6,10]$ and that extra supplementation of leucine promotes CLS extension in standard $2 \%$ glucose medium [6]. Recently, it has also been shown that leucine influences autophagy and extension of CLS during CR [14]. 
The target of rapamycin complex 1 (TORC1) controls cell growth in response to the availability of nutrients, including amino acids $[15,16]$. The TOR pathway responds to nitrogen by regulating processes such as the transcription of genes involved in nitrogen metabolism: nitrogen catabolite repression (NCR) sensitive genes, amino acid biosynthesis genes (general amino acid control pathway-GAAC), retrograde response genes (RTG-Pathway), and genes involved in the stability of amino acid permeases and autophagy $[17,18]$. In mammalian cells, amino acids, predominantly leucine, regulate mTOR by controlling the ability of the positive regulator Rheb-GTP to activate mTORC1. The fundamental role of leucine in TORC1 regulation has been demonstrated through the observation that withdrawal of leucine alone is almost as effective in downregulating TORC1 as withdrawal of all amino acids combined [19]. In yeast, the EGO complex is an upstream regulator of TORC1, thought to be responsible for amino acid signaling to TORC1. During leucine starvation, TORCl activation by this complex is disrupted, which results in a reduction in Sch9p phosphorylation and slow growth $[20,21]$.

The protein kinase A (PKA) pathway is involved in the regulation of metabolism, stress response, and proliferation, responding to the presence of a rapidly fermentable sugar and other essential nutrients sustaining growth, such as amino acids and phosphate $[16,22]$. Readdition of nitrogen (amino acids or ammonium) to cells starved for nitrogen activates the PKA pathway through plasma membrane sensors known as transceptors. Sch9p is a protein kinase that shares many targets with PKA and TORC1, and different interactions between these pathways, either cooperating or antagonizing their effects, have been described [23]. It was shown that Sch9p mediates PKA activation in the fermentable growth medium induced (FGM) pathway, in response to amino acid and ammonium, but not in phosphate-induced activation [24].

We have previously shown that decreasing the ammonium $\left(\mathrm{NH}_{4}{ }^{+}\right)$concentration in the culture medium extends the CLS of Saccharomyces cerevisiae BY4742 cells [25]. $\mathrm{NH}_{4}{ }^{+}$ reduced the CLS of cells cultured to stationary phase under both standard amino acid supplementation and amino acid restriction conditions in a concentration-dependent manner, and a significant increase in cell survival was observed when the starting $\mathrm{NH}_{4}{ }^{+}$concentration in the medium was decreased. We also showed that when stationary phase cells were transferred to water, the CLS was also significantly shortened by addition of $\mathrm{NH}_{4}{ }^{+}$, indicating that $\mathrm{NH}_{4}{ }^{+}$alone could induce the loss of cell viability observed in culture media. The negative effects of $\mathrm{NH}_{4}{ }^{+}$were particularly evident in cells cultured or incubated under restriction of auxotrophy-complementing amino acid markers (leucine, lysine, and histidine). These negative effects of $\mathrm{NH}_{4}^{+}$do not appear to require its metabolization. The PKA and TOR pathways were involved in $\mathrm{NH}_{4}{ }^{+}$-induced CLS shortening, but deleting $\mathrm{SCH} 9$ did not revert the decrease in cell viability despite abolishing PKA activation in response to $\mathrm{NH}_{4}{ }^{+}$, suggesting Sch9p plays an independent role in cell survival [25].
Here, we show that $\mathrm{NH}_{4}{ }^{+}$toxicity during yeast aging in water depends on the specific starved auxotrophy-complementing amino acid. Sch9p, contrary to Torlp and Ras $2 p$, mediates cell survival in response to $\mathrm{NH}_{4}{ }^{+}$in all starvation conditions through the phosphorylation of Hoglp. Our results provide new insights in the modulation of CLS by $\mathrm{NH}_{4}{ }^{+}$, linking $\mathrm{NH}_{4}{ }^{+}$toxicity to amino acid limitation. This scenario of enhanced $\mathrm{NH}_{4}{ }^{+}$toxicity in amino acid starvation conditions is present in hyperammonemic patients, who are often on dietary protein restriction [26]. The use of a simpler model like yeast can help elucidate the underlying mechanism involved in the modulation of conserved signaling pathways, in response to $\mathrm{NH}_{4}{ }^{+}$.

\section{Materials and Methods}

2.1. Strains and Growth Conditions. Saccharomyces cerevisiae strain BY4742 (MATa his $3 \Delta 1$ leu $2 \Delta 0$ lys $2 \Delta 0$ ura $3 \Delta 0$ ) (EUROSCARF, Frankfurt, Germany) and the respective knockouts in HOG1, RAS2, SCH9, and TOR1 genes were used. For experiments with nonstarved and amino-acid-starved cells, the strains were first cultured at $26^{\circ} \mathrm{C}, 150 \mathrm{rpm}$, in defined minimal medium (SC medium) containing $0.17 \%$ yeast nitrogen base without amino acids and without ammonium sulphate (Difco, BD), supplemented with $0.5 \%$ $\left(\mathrm{NH}_{4}\right)_{2} \mathrm{SO}_{4}$, with appropriate amino acids and nucleotide base $(50 \mathrm{mg} / \mathrm{L}$ histidine, $50 \mathrm{mg} / \mathrm{L}$ lysine, $300 \mathrm{mg} / \mathrm{L}$ leucine, and $100 \mathrm{mg} / \mathrm{L}$ uracil) and $2 \%$ D-glucose, to exponential phase $\left(\mathrm{OD}_{600}=1.0-1.5\right)$. These cells were harvested and resuspended in (A) SC medium containing 4\% glucose (nonstarved cells) or in (B) SC medium containing 4\% glucose and lacking (1) amino acids (aa-starved cells); (2) leucine (Leu-starved cells); (3) histidine (His-starved cells); (4) lysine (Lys-starved cells); (5) histidine and lysine (His-Lys-starved cells); (6) leucine and lysine (Leu-Lys-starved cells), and (7) leucine and histidine (Leu-His-starved cells). After 24 hours, cells were collected by centrifugation, washed three times with water, and resuspended at a cell density of about $3.8 \times 10^{7}$ cells $/ \mathrm{mL}$ in water $(\mathrm{pH} 7.0)$, or water with $\left(\mathrm{NH}_{4}\right)_{2} \mathrm{SO}_{4}$ (0.5\%, pH 7.0). Viability of 24-hour-starved cultures was considered to be $100 \%$ of survival, and this was considered day 0 of the experiment. pH 7.0 was maintained throughout the experiment in cultures with adjusted $\mathrm{pH}$. Cell viability of culture aliquots was assessed by CFU at day 0 (100\% viability) and in subsequent days, as indicated. For CFU determination, diluted samples were incubated for 2 days at $30^{\circ} \mathrm{C}$ on YEPD agar plates.

2.2. Trehalase Activity. Trehalase activity was determined according to [27]. Briefly, crude enzyme extracts were obtained by resuspending the cell pellet in ice-cold $50 \mathrm{mM}$ MES/KOH buffer (pH 7.0) containing $50 \mu \mathrm{M} \mathrm{CaCl}_{2}$ and adding a roughly equal volume of $0.5 \mathrm{~mm}$ diameter glass beads, followed by vigorous mixing during 1 minute intervals interspersed with periods of cooling on ice. The extracts were then dialyzed overnight at $4^{\circ} \mathrm{C}$ in a dialysis cellulose membrane (Cellu Sep H1, Orange). The dialyzed extract was then used to assess trehalase activity by measuring the released glucose using a glucose oxidase assay (GOD, Roche). 
Protein concentration was determined using the Bradford assay (Bio-Rad, Germany) according to the manufacturer's instructions.

2.3. Western Blot Analysis. Western blot analysis was performed according to [28]. Briefly, protein lysates were separated on $12.5 \%$ SDS-PAGE gels and transferred to polyvinylidene fluoride membranes (Hybond-P; Amersham). The membranes were blocked with $5 \%$ bovine serum albumin (BSA) in Tris-buffered saline (TBS, $50 \mathrm{mM}$ Tris, $150 \mathrm{mM}$ $\mathrm{NaCl}$, and $\mathrm{pH} 7.6$ ) containing $0.05 \%$ Tween 20 for $1 \mathrm{~h}$ at room temperature. Membranes were then incubated overnight at $4^{\circ} \mathrm{C}$ with primary antibodies directed against Hoglp (rabbit anti-Hoglp MAPK; Santa Cruz Biotechnology, Inc., USA) at a 1:1000 dilution or rabbit anti-phospho-p38 MAPK (Cell Signaling Technology, Beverly, MA, USA) at a 1:50000 dilution and against Pgklp (mouse monoclonal anti-PGK1; Molecular Probes) at a 1:5000 dilution. This was followed by a onehour incubation at room temperature with secondary antibody Peroxidase-AffiniPure Goat AntiRabbit IgG (1:10000; Jackson ImmunoResearch) or Peroxidase-AffiniPure Goat AntiMouse IgG (1:10000; Jackson ImmunoResearch).

\section{Results and Discussion}

3.1. $\mathrm{NH}_{4}{ }^{+}$-Induced Cell Death during Yeast Aging in Water Depends on the Specific Auxotrophy-Complementing Amino Acid Deprived from the Starvation Medium. In Saccharomyces cerevisiae $\mathrm{BY} 4742, \mathrm{NH}_{4}{ }^{+}$leads to chronological life span (CLS) shortening, particularly relevant in cells starved for the auxotrophy-complementing amino acids simultaneously. The effect of $\mathrm{NH}_{4}{ }^{+}$has been observed both in cells aged in spent culture medium limited for the essential amino acids and in cells aged in water after a 24-hour incubation in amino-acid-deprived medium [25]. We now sought to evaluate how the absence of specific auxotrophycomplementing amino acids affects $\mathrm{NH}_{4}{ }^{+}$toxicity during yeast CLS. For this purpose, cells were first grown to exponential phase in SC medium and then starved for each of the three essential amino acids of the BY4742 strain (leucine, lysine, and histidine) alone or in combinations of two, as well as in their absence (aa-starved cells). As a control, we used the same medium, but without amino acid deprivation, therefore adding the three auxotrophycomplementing amino acids (nonstarved cells). Cells were then transferred to water with and without $\mathrm{NH}_{4}{ }^{+}$, and cell viability was evaluated over time. The protocol followed is systematized in Figure S1 in Supplementary material available online at http://dx.doi.org/10.1155/2013/161986.

The results presented in Figure 1(a) revealed that aa-, lysine- (Lys-), or nonstarved cells displayed a longer CLS in water without $\mathrm{NH}_{4}^{+}$than leucine- (Leu-) or histidine(His-) starved cells. Furthermore, absence of any of the three amino acids in the medium, individually or at the same time, decreased CLS upon transfer of cells to water with $\mathrm{NH}_{4}{ }^{+}$, in comparison with the CLS of cells incubaed without amino acid restriction, though this effect was much less accentuated when only lysine was removed (Figure 1(b)). Two of the amino acids were then removed at the same time in different combinations (Figures 1(c) and 1(d)). Simultaneous absence of lysine and histidine (Lys-His-starved cells) had the least effect on $\mathrm{NH}_{4}{ }^{+}$-induced CLS shortening (Figure 1(d)), whereas $\mathrm{NH}_{4}{ }^{+}$was most toxic to cells starved both for leucine and histidine (Leu-His starved cells). Comparing these results with those from Figure 1(b) (removal of one amino acid at a time from the medium), it can be observed that survival of Leu- or His-starved cells in water with $\mathrm{NH}_{4}{ }^{+}$was much lower than that of cells that were also starved for lysine (Leu-Lys- or His-Lys-starved cells). On the other hand, the opposite effect was observed if Lysor His-starved cells were simultaneously starved for leucine (Lys-Leu- or His-Leu-starved cells), where $\mathrm{NH}_{4}{ }^{+}$-induced CLS shortening was more severe. Additionally, histidine starvation in combination with one of the other two amino acids does not appear to have a major role in regulating CLS in response to $\mathrm{NH}_{4}{ }^{+}$, since the cell death profiles under those conditions were similar to those exhibited by Lys- or Leustarved cells.

Taken together, the results suggest that from the three auxotrophy-complementing amino acids tested, starvation for leucine alone or in combination with histidine resulted in the most severe effects on $\mathrm{NH}_{4}{ }^{+}$-induced CLS shortening, while starvation for lysine, alone or in combination with histidine, resulted in the less sensitive $\mathrm{NH}_{4}{ }^{+}$phenotype.

3.2. Ras2p, Torlp, and Sch9p Differently Mediate $\mathrm{NH}_{4}{ }^{+}$Induced Cell Death during Yeast Aging in Water. The toxic effects of $\mathrm{NH}_{4}{ }^{+}$in aa-starved BY4742 cells are the result of activation of the PKA and TOR pathways and are negatively regulated by Sch9p [25]. In addition, the results shown in the previous section demonstrated that ammonium affects CLS shortening depending on the specific essential amino acid deprived from the medium. We therefore sought to elucidate the role of Ras2/PKA, Torlp, and Sch9p signaling pathways in CLS shortening induced by $\mathrm{NH}_{4}{ }^{+}$under the different starvation conditions. For this, we first tested the effect of starving $\operatorname{tor} 1 \Delta, \operatorname{ras} 2 \Delta$, and $\operatorname{sch} 9 \Delta$ cells for each of the three auxotrophy-complementing amino acids individually. As a control, we used the same medium in the absence or presence of all three essential amino acids. Similarly to what we described above, cells were first grown to exponential phase in SC medium, then incubated in the different starvation media, and next transferred to water with or without $\mathrm{NH}_{4}{ }^{+}$ (For schematic representation of the protocol please see Figure S1).

The tor $1 \Delta$ strain displayed a lower $\mathrm{NH}_{4}{ }^{+}$-induced cell death than the wild-type strain in all starvation conditions tested (Figures 1(b) and 2(b)). Furthermore, Lys-starved cells displayed almost the same loss of cell viability as nonstarved cells in the presence of $\mathrm{NH}_{4}{ }^{+}$, showing that starvation for this amino acid does not induce sensitivity to $\mathrm{NH}_{4}{ }^{+}$in the absence of TOR1. For nonstarved cells, there was no difference in the effect of $\mathrm{NH}_{4}{ }^{+}$between wild-type and tor $1 \Delta$ strains. On the other hand, deletion of TOR1 also rescued the CLS of Hisstarved cells in water without $\mathrm{NH}_{4}{ }^{+}$(Figures 1(a) and 2(a)).

In the ras $2 \Delta$ strain, the loss of cell viability induced by $\mathrm{NH}_{4}{ }^{+}$in nonstarved cells or Lys-starved cells was significantly reduced when compared with the wild-type 

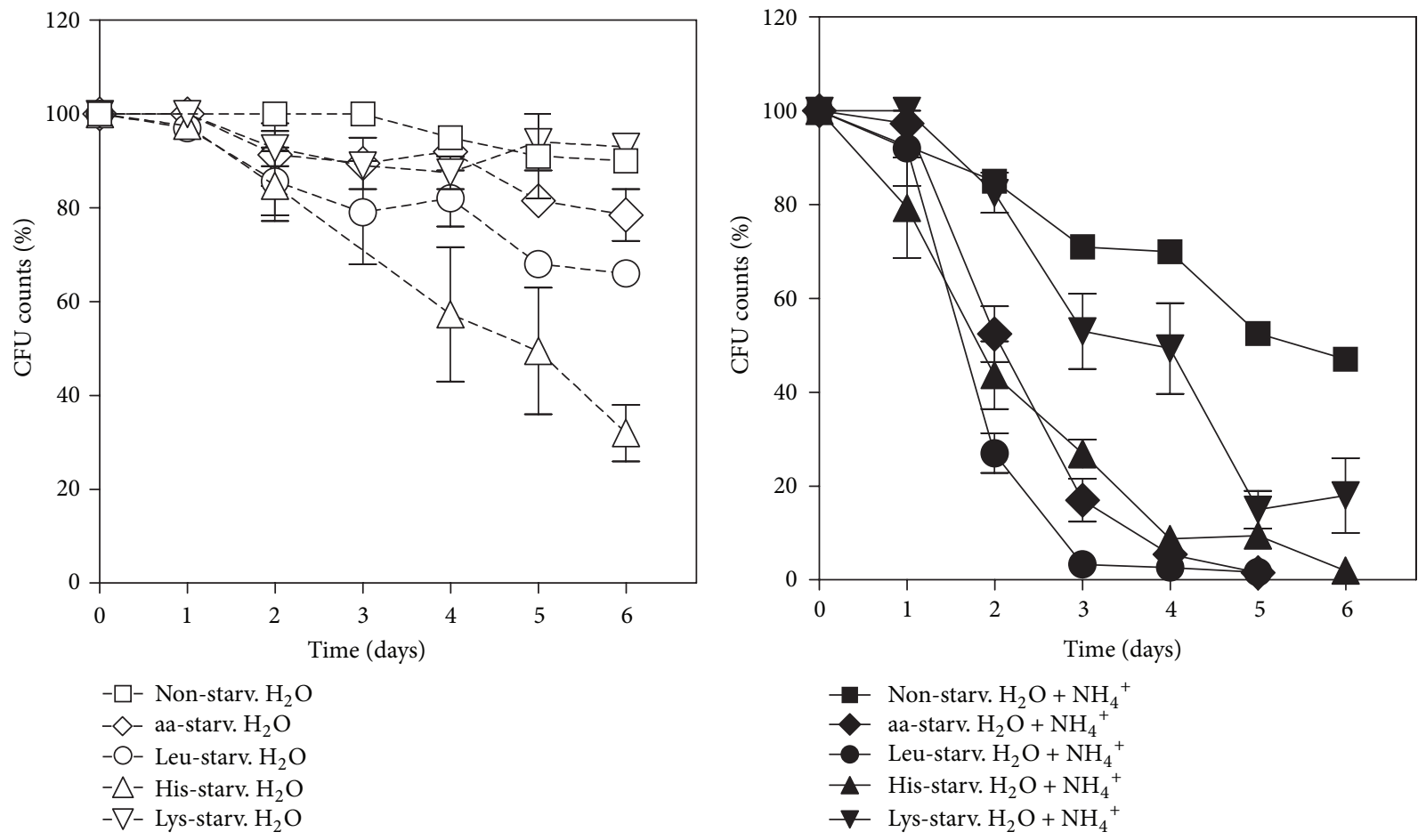

(a)

(b)

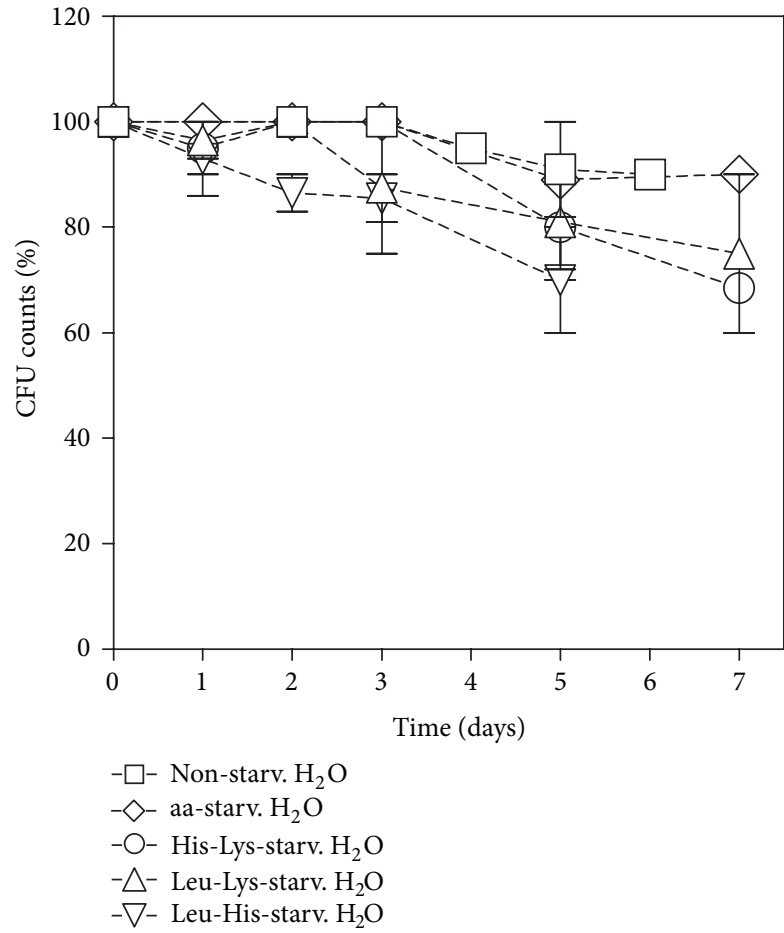

(c)

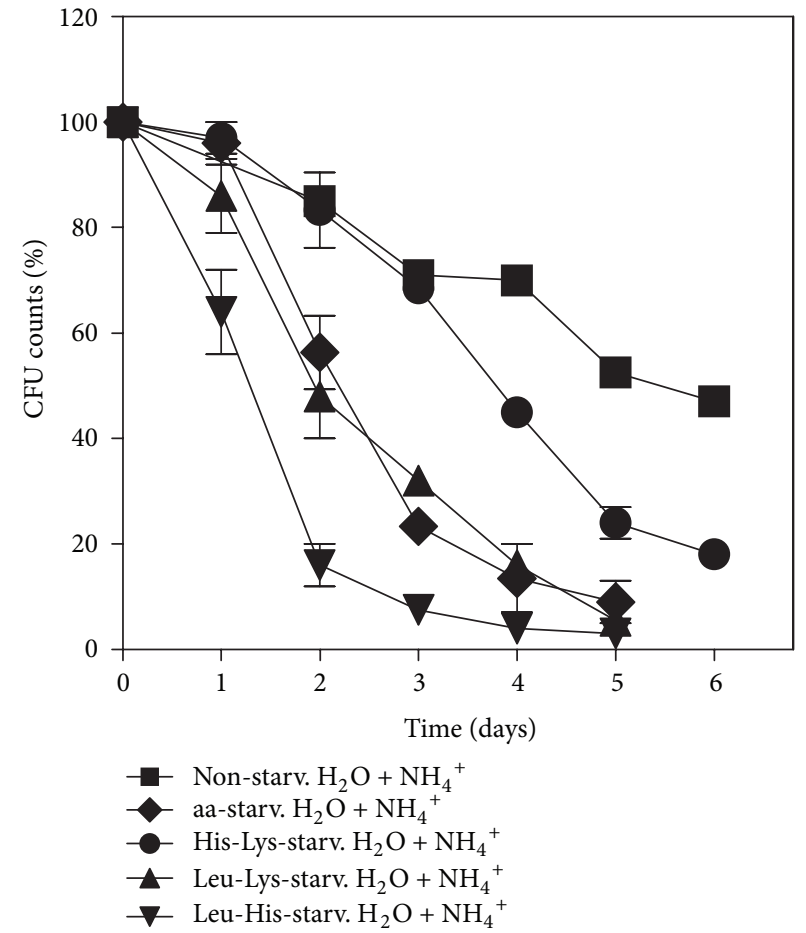

(d)

FIGURE 1: Ammonium-induced cell death during yeast aging in water is dependent on the specific auxotrophy-complementing amino acid deprived from the starvation medium. Survival of wild-type S. cerevisiae (BY4742) cells, nonstarved or starved for leucine, histidine, or lysine, in different combinations upon ((a) and (c)) transfer to water (open symbol) or ((b) and (d)) water with $\left(\mathrm{NH}_{4}\right)_{2} \mathrm{SO}_{4}, 0.5 \%($ dark symbol). In all the cultures, starting cell density was about $3.8 \times 10^{7}$ cells $/ \mathrm{mL}$, and the initial $\mathrm{pH}$ was adjusted to 7.0. Values are means $\pm \mathrm{SEM}(n=3)$. (b) ${ }^{* *} \mathrm{P}<0.01$ (aa-starved $\mathrm{H}_{2} \mathrm{O}+\mathrm{NH}_{4}{ }^{+}$versus Lys-starved $\mathrm{H}_{2} \mathrm{O}+\mathrm{NH}_{4}{ }^{+}$), ${ }^{* *} \mathrm{P}<0.01$ (aa-starved $\mathrm{H}_{2} \mathrm{O}+\mathrm{NH}_{4}{ }^{+}$versus Leu-starved $\mathrm{H}_{2} \mathrm{O}$ $+\mathrm{NH}_{4}{ }^{+}$), and ${ }^{* * *} \mathrm{P}<0.001$ (nonstarved $\mathrm{H}_{2} \mathrm{O}+\mathrm{NH}_{4}{ }^{+}$versus Lys-starved $\mathrm{H}_{2} \mathrm{O}+\mathrm{NH}_{4}{ }^{+}$); (d) ${ }^{*} \mathrm{P}<0.01$ (nonstarved $\mathrm{H}_{2} \mathrm{O}+\mathrm{NH}_{4}{ }^{+}$versus His-Lys-starved $\mathrm{H}_{2} \mathrm{O}+\mathrm{NH}_{4}{ }^{+}$), ${ }^{* *} \mathrm{P}<0.01$ (aa-starved $\mathrm{H}_{2} \mathrm{O}+\mathrm{NH}_{4}{ }^{+}$versus Leu-His-starved $\mathrm{H}_{2} \mathrm{O}+\mathrm{NH}_{4}{ }^{+}$), and ${ }^{* * *} \mathrm{P}<0.001$ (aa-starved $\mathrm{H}_{2} \mathrm{O}+\mathrm{NH}_{4}{ }^{+}$versus His-Lys-starved $\mathrm{H}_{2} \mathrm{O}+\mathrm{NH}_{4}{ }^{+}$). Statistical analysis was performed by two-way ANOVA. All time points have error bars; however, for time points with reduced standard error, they are not visible. 


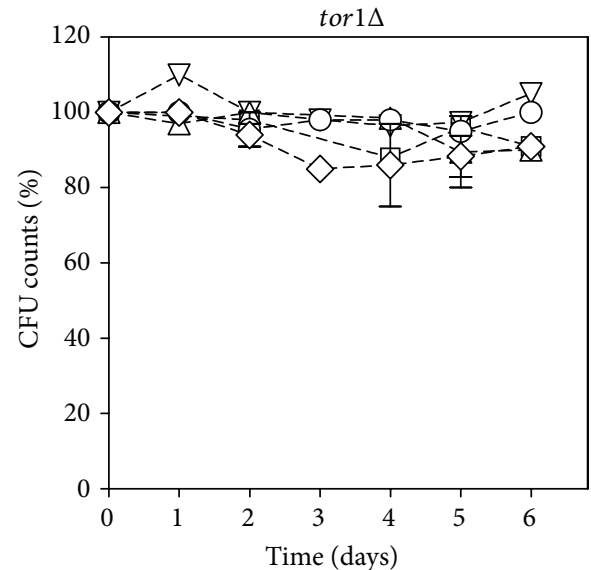

(a)

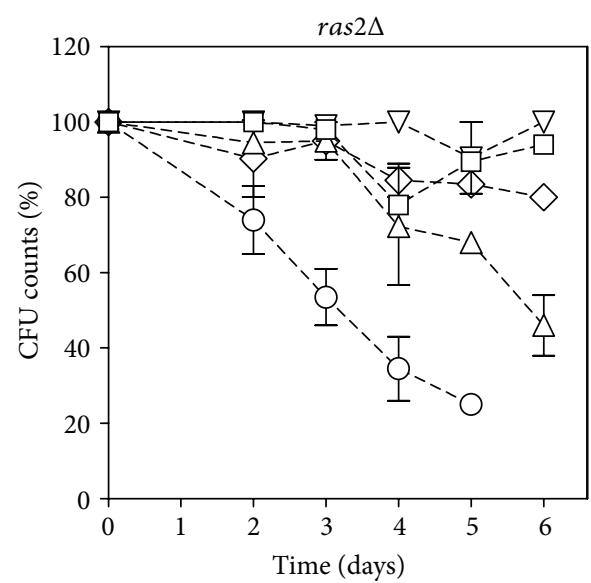

(c)

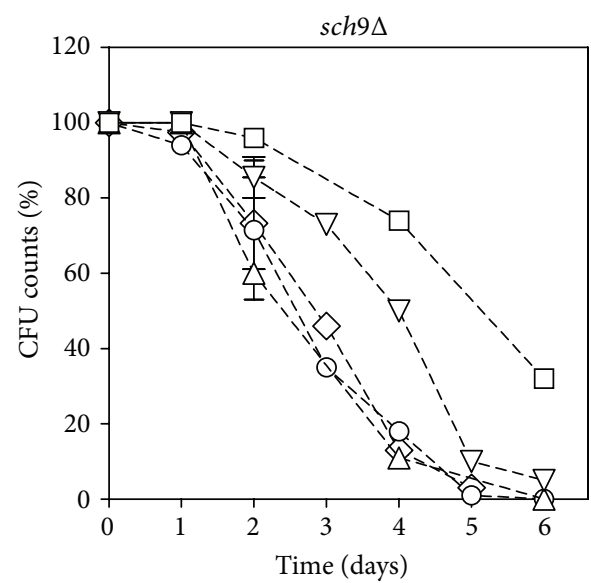

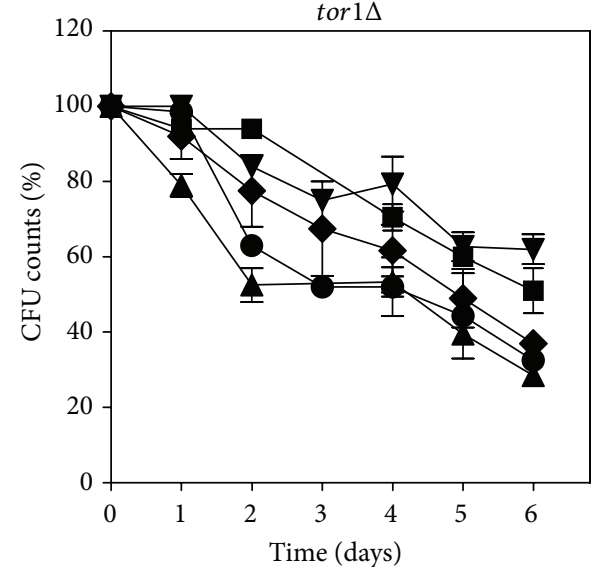

(b)

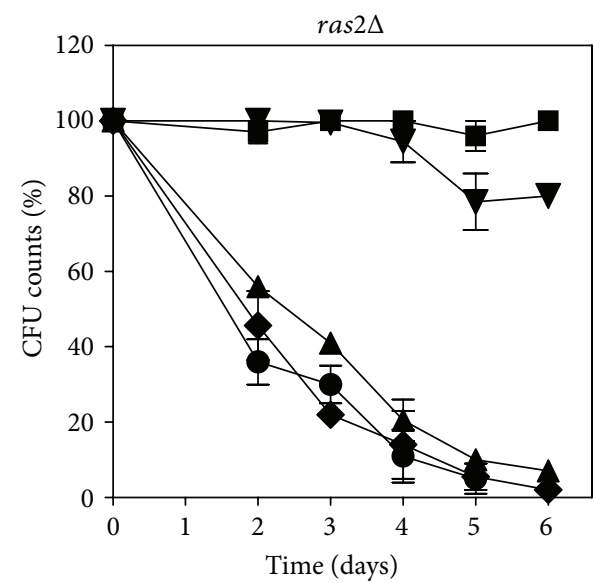

(d)

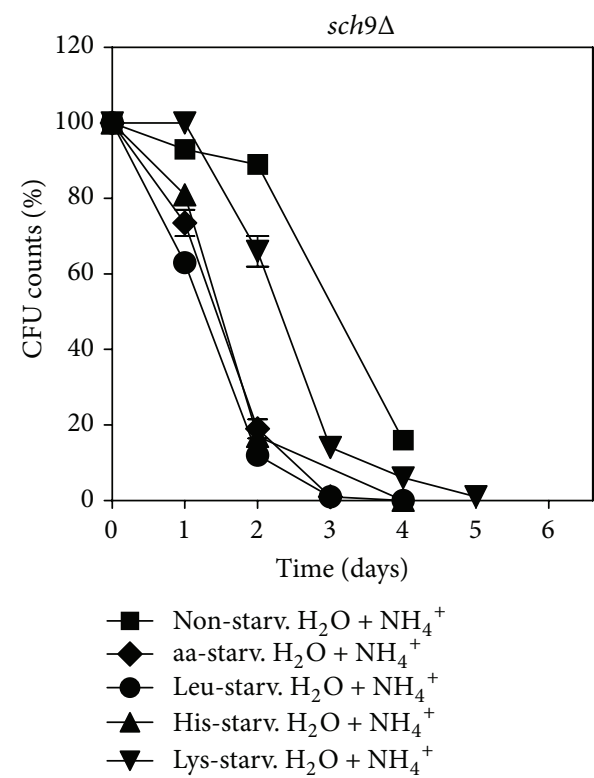

(f)

FIGURE 2: Torlp regulates ammonium CLS shortening in response to amino acid starvation. Survival of ((a) and (b)) torl $\Delta$, ((c) and (d)) ras $2 \Delta$, and ((e) and (f)) sch $9 \Delta$ cells, nonstarved or starved for leucine, histidine, or lysine, individually or all at the same time, upon transfer to water (open symbol) or water with $\left(\mathrm{NH}_{4}\right)_{2} \mathrm{SO}_{4}, 0.5 \%$ (dark symbols). In all the cultures, starting cell density was about $3.8 \times 10^{7}$ cells $/ \mathrm{mL}$, and the initial $\mathrm{pH}$ was adjusted to 7.0. Values are means $\pm \operatorname{SEM}(n=3)$. All time points have error bars; however, for time points with reduced standard error, they are not visible. 
strain. In contrast, deletion of RAS2 had only a slight effect on the sensitivity of His- or Leu-starved cells to $\mathrm{NH}_{4}{ }^{+}$, as well as of cells starved for all three amino acids (aa-starved cells). Furthermore, for the last two starvation conditions, deletion of RAS2 induced a strong shortening of CLS in water without $\mathrm{NH}_{4}{ }^{+}$, indicating that Ras2 $\mathrm{p}$ is important to ensure longevity under these conditions (Figures 1(a) and 2(c)).

Absence of Sch9p reduced survival after cells were transferred to water with or without $\mathrm{NH}_{4}{ }^{+}$for all conditions tested (starved or nonstarved). Data from Figures 2(e) and 2(f) show that Leu- or His-starved cells of the $\operatorname{sch} 9 \Delta$ strain behaved as aa-starved cells when transferred to water with or without $\mathrm{NH}_{4}{ }^{+}$. In non- or Lys-starved cells, the loss of cell viability in water, with or without $\mathrm{NH}_{4}{ }^{+}$, was much less pronounced than in the other starvation conditions, as observed for wildtype cells.

3.3. Ras2p, Torlp, and Sch9p Mediate PKA Activation in Response to $\mathrm{NH}_{4}^{+}$during Yeast Aging in Water. To further evaluate the role of PKA in $\mathrm{NH}_{4}{ }^{+}$-induced CLS shortening and the potential effects of Torlp, Ras2p, and Sch9p as PKA upstream regulators, we assessed PKA activation in BY4742 (wild-type), tor $1 \Delta, \operatorname{ras} 2 \Delta$, and $\operatorname{sch} 9 \Delta$ strains starved for each of the three essential amino acids, individually or in combination. Trehalase is a target of PKA regulation, and its activity has been extensively used to monitor PKA activation $[22,29]$. In order to evaluate PKA activation, we therefore measured trehalase activity in cells grown and incubated as described above in material and methods section. (For schematic representation of the protocol please see Figure S1). We observed that in wild-type cells, leucine starvation resulted in the highest trehalase activity after $2 \mathrm{~h}$ of incubation with $\mathrm{NH}_{4}{ }^{+}$, whereas its presence alone led to the lowest trehalase activity. In contrast, and under the same conditions, starvation for lysine or histidine alone gave rise to the lowest trehalase activity, whereas their presence alone led to the highest trehalase activity (Figure 3(a)). The results also showed that in the presence of $\mathrm{NH}_{4}{ }^{+}$, aa-starved cells exhibited a PKA activation pattern similar to nonstarved cells, with values that are between those obtained for Leuand His- or Lys-starved cells. This suggests that in aastarved cells, the higher contribution expected from PKA activation due to the absence of leucine is probably balanced by the decrease of PKA activity induced by the absence of histidine and lysine. PKA activation by $\mathrm{NH}_{4}{ }^{+}$was decreased in $\operatorname{tor} 1 \Delta$, ras $2 \Delta$, and $\operatorname{sch} 9 \Delta$ mutants in comparison with the wild-type strain, both for nonstarved cells and under all amino acid starvation conditions (Figures 3(b), 3(c), and $3(\mathrm{~d})$ ). The observed reduction in PKA activation correlates with the decrease in $\mathrm{NH}_{4}{ }^{+}$-induced CLS shortening in the tor $1 \Delta$ strain under all the conditions tested. In addition, the decrease in PKA activation induced by $\mathrm{NH}_{4}{ }^{+}$in the ras $2 \Delta$ strain was accompanied by an increase in cell survival for non- or lysine-starved cells, but not for cells under the remaining starvation conditions (Leu-, His-, or aa-starved cells). Conversely, for nonstarved cells and for cells starved in the presence of leucine (His-starved and Lys-starved cells) before transfer to water (T0), there was a significant increase in PKA activation in the ras $2 \Delta$ strain, indicating that Ras $2 p$ seems to downregulate PKA activity in the presence of leucine. On the other hand, the decrease in PKA activation induced by $\mathrm{NH}_{4}{ }^{+}$in the $\operatorname{sch} 9 \Delta$ strain was not associated with an extended CLS in water with $\mathrm{NH}_{4}{ }^{+}$in nonstarved cells or under any of the starvation conditions tested, which is in accordance with previous results described for aastarved cells [25]. Together, the results suggest that $\mathrm{NH}_{4}{ }^{+}$ induces PKA activation through Torlp, Ras2p, and Sch9p. However, absence of Ras2p, although able to decrease PKA activation, did not revert $\mathrm{NH}_{4}{ }^{+}$-induced CLS shortening in Leu-, His-, and aa-starved cells, indicating that in the absence of this protein, other pathways, independent of PKA and possibly mediated by Torlp, are still activated and can induce cell death. Furthermore, Ras2p, at least under some conditions, appears to also activate other pathways relevant to cell survival, since its absence leads to a shorter CLS in water. A prosurvival role was also observed for Sch9p under all conditions, either in the absence or presence of $\mathrm{NH}_{4}{ }^{+}$.

3.4. Sch9p Protects Cells from $\mathrm{NH}_{4}{ }^{+}$-Induced Cell Death through Hoglp Activation. Hoglp is a kinase that regulates and is regulated by Sch9p and mediates stress response independently of the PKA and TOR pathways [30]. It was previously shown that Hoglp is involved in the resistance of aa-starved cells to the toxic effects of $\mathrm{NH}_{4}{ }^{+}$during CLS in water [25]. In order to access if the protective role of Sch9p in response to $\mathrm{NH}_{4}{ }^{+}$under the different amino acid starvation conditions described in the previous sections could be mediated through a Sch9p-dependent Hoglp activation, we examined Hoglp phosphorylation during CLS in water with and without $\mathrm{NH}_{4}{ }^{+}$in BY4742 (wild-type) and $\operatorname{sch} 9 \Delta$ cells. As shown in Figure 4, Hoglp phosphorylation in wild-type cells increased in the presence of $\mathrm{NH}_{4}{ }^{+}$in all starvation conditions tested (aa-, Leu-, His-, and Lys-starved cells), being higher in His- and Lys-starved cells. Deletion of SCH9 almost abolished Hoglp phosphorylation in aa-, Leu-, and His-starved cells, whereas some residual phosphorylation was still detected in Lys-starved cells. The lower Hoplp phosphorylation observed for cells starved for aa- and Leu-starved cells is in agreement with previous results, showing that the presence of leucine is required for Sch9p phosphorylation via TORC1 [21]. Also, Hoglp phosphorylation in Lys-starved sch $9 \Delta$ cells is in agreement with the activation of pathways other than the PKA in the absence of Ras2p, suggested by the rescue of the loss of viability found for Lys-starved ras $2 \Delta$ cells (Figure $2(\mathrm{~d})$ ).

Taken together, results show that Sch9p is involved in Hoglp activation in response to $\mathrm{NH}_{4}{ }^{+}$under all starvation conditions, indicating that the increased resistance afforded by Sch9p could, actually, be mediated through Hoglp activation.

\section{Conclusions}

It has been previously shown that the CLS of stationary phase cells of Saccharomyces cerevisiae BY4742 transferred to water was significantly shortened by the addition of $\mathrm{NH}_{4}^{+}$and that the negative effects of $\mathrm{NH}_{4}{ }^{+}$were particularly evident for cells under restriction of auxotrophy-complementing amino acid markers (leucine, lysine, and histidine) [25]. The 


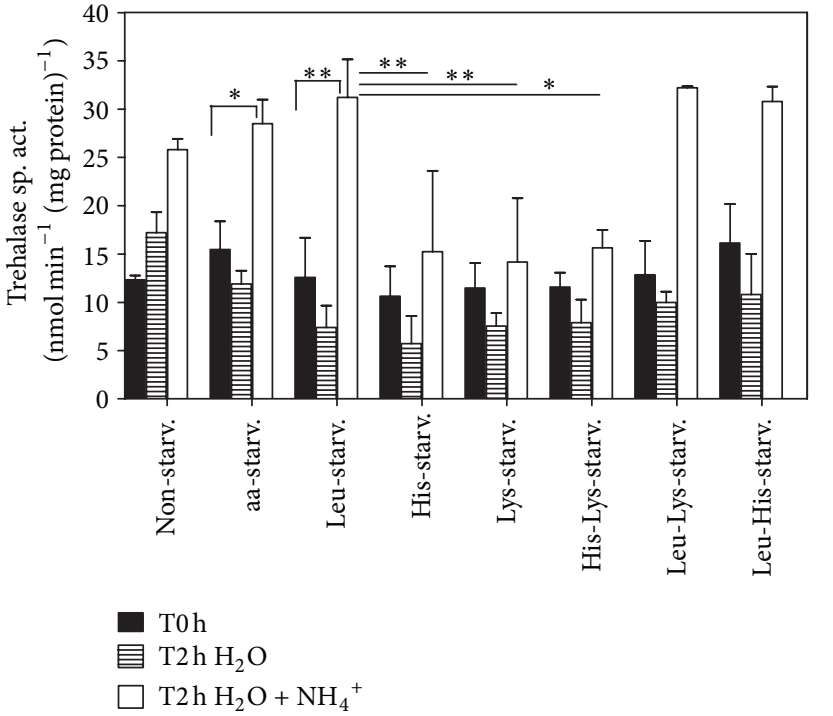

(a)

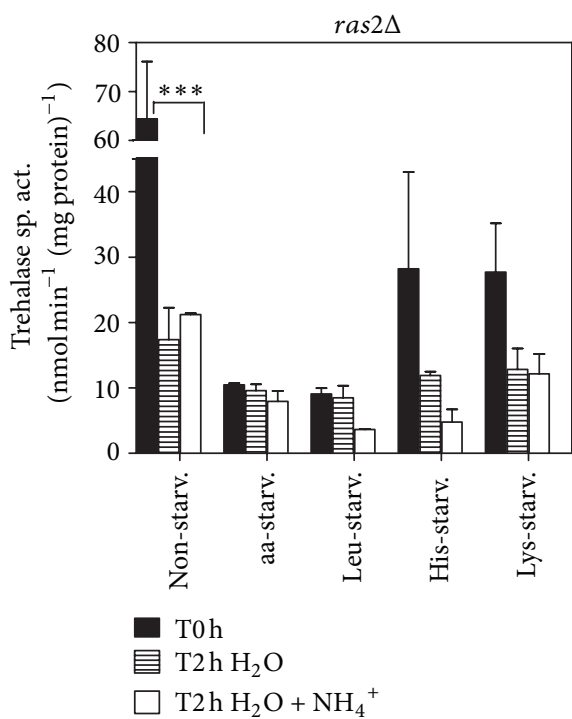

(c)

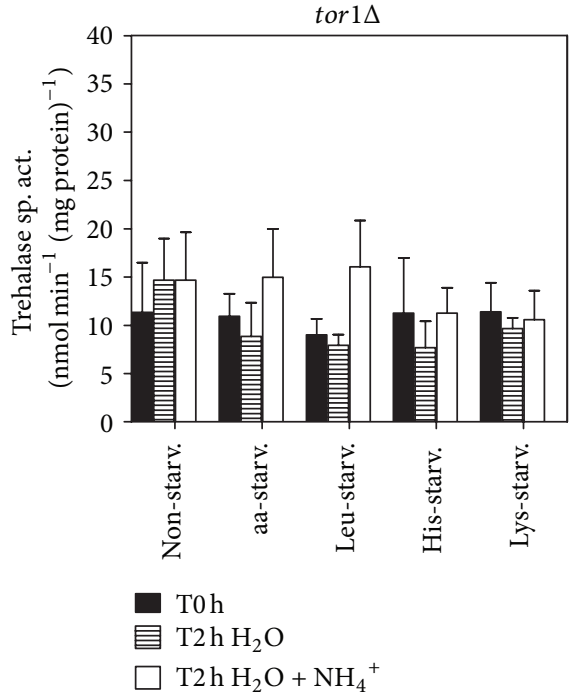

(b)

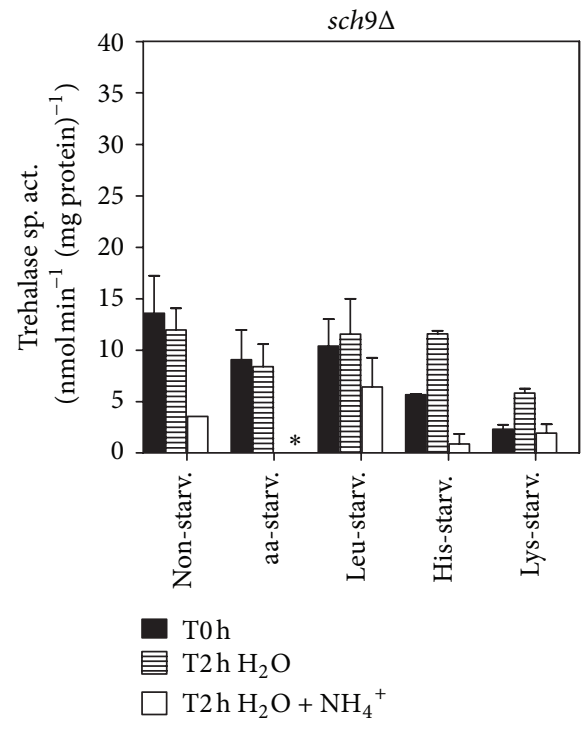

(d)

FIgURE 3: Ammonium induction of PKA activity depends on Torlp, Ras2p and Sch9p regulation. Trehalase activity of cells nonstarved or starved for leucine, histidine, or lysine, individually or in different combinations, of (a) wild-type S. cerevisiae (BY4742) and of mutant deleted strains (b) tor $1 \Delta$, (c) ras $2 \Delta$, and (d) $s c h 9 \Delta$; before being, transferred to water (T0h) and after 2 hours in water (T2h $\mathrm{H}_{2} \mathrm{O}$ ) or water with $\left(\mathrm{NH}_{4}\right)_{2} \mathrm{SO}_{4}, 0.5 \%\left(\mathrm{~T} 2 \mathrm{~h} \mathrm{H}_{2} \mathrm{O}+\mathrm{NH}_{4}{ }^{+}\right)$. In all the cultures, starting cell density was about $3.8 \times 10^{7}$ cells/mL, and the initial $\mathrm{pH}$ was adjusted to 7.0. Values are means $\pm \operatorname{SEM}(n=3-4)$. (a) ${ }^{*} P<0.05$ (aa-starved T0h versus aa-starved $\left.\mathrm{T} 2 \mathrm{~h} \mathrm{H}_{2} \mathrm{O}+\mathrm{NH}_{4}{ }^{+}\right),{ }^{* *} P<0.01$ (Leu-starved T0h versus Leu-starved T2 $\mathrm{H}_{2} \mathrm{O}+\mathrm{NH}_{4}{ }^{+}$), ${ }^{* *} \mathrm{P}<0.01$ (Leu-starved $\mathrm{T} 2 \mathrm{~h} \mathrm{H}_{2} \mathrm{O}+\mathrm{NH}_{4}{ }^{+}$versus His-starved $\mathrm{T} 2 \mathrm{~h} \mathrm{H}_{2} \mathrm{O}+\mathrm{NH}_{4}{ }^{+}$), ${ }^{* *} \mathrm{P}<0.01$ (Leu-starved T2 $\mathrm{h} \mathrm{H}_{2} \mathrm{O}+\mathrm{NH}_{4}{ }^{+}$versus Lys-starved T2 $\mathrm{h}_{2} \mathrm{O}+\mathrm{NH}_{4}{ }^{+}$), ${ }^{*} \mathrm{P}<0.05$ (Leu-starved T2 $\mathrm{h}_{2} \mathrm{O}+\mathrm{NH}_{4}{ }^{+}$versus His-Lys-starved T2h $\mathrm{H}_{2} \mathrm{O}+\mathrm{NH}_{4}^{+}$); (c) ${ }^{* * *} \mathrm{P}<0.001$ (nonstarved T0h versus nonstarved $\mathrm{H}_{2} \mathrm{O}+\mathrm{NH}_{4}^{+}$); (d) ${ }^{*} \mathrm{P}<0.05$ (aa-starved T0h versus aa-starved T2h $\mathrm{H}_{2} \mathrm{O}+\mathrm{NH}_{4}^{+}$). Statistical analysis was performed by two-way and one-way ANOVA.

results presented herewith demonstrate that $\mathrm{NH}_{4}{ }^{+}$-induced cell death during aging in water depends on the specific auxotrophy-complementing amino acid deprived from the starvation medium. While Lys-starved cells were only slightly more sensitive to $\mathrm{NH}_{4}{ }^{+}$-induced CLS shortening than nonstarved cells, Leu- and His-starved cells displayed a much stronger sensitivity to $\mathrm{NH}_{4}^{+}$during CLS, which was comparable to that previously described for cells simultaneously starved for all three essential amino acids (aa-starved cells). When we compare cells starved for one amino acid at a time with nonstarved cells, absence of any of the three auxotrophycomplementing amino acids from the medium has a detrimental effect leading to a faster loss of cell survival in response to ammonium. However, when cells are starved for at least one amino acid, the presence of lysine in the medium is detrimental, histidine does not seem to have an effect, and 


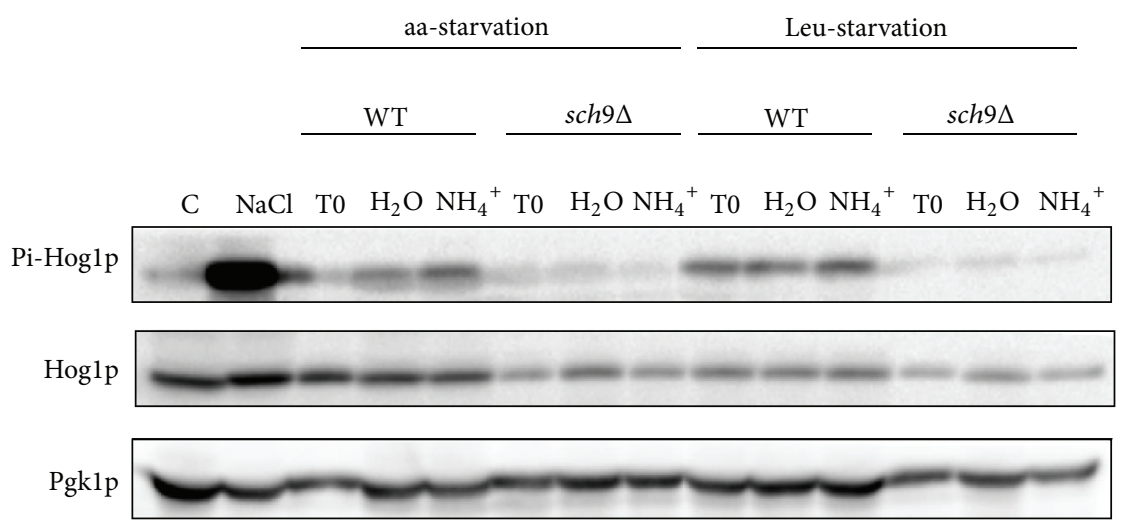

(a)

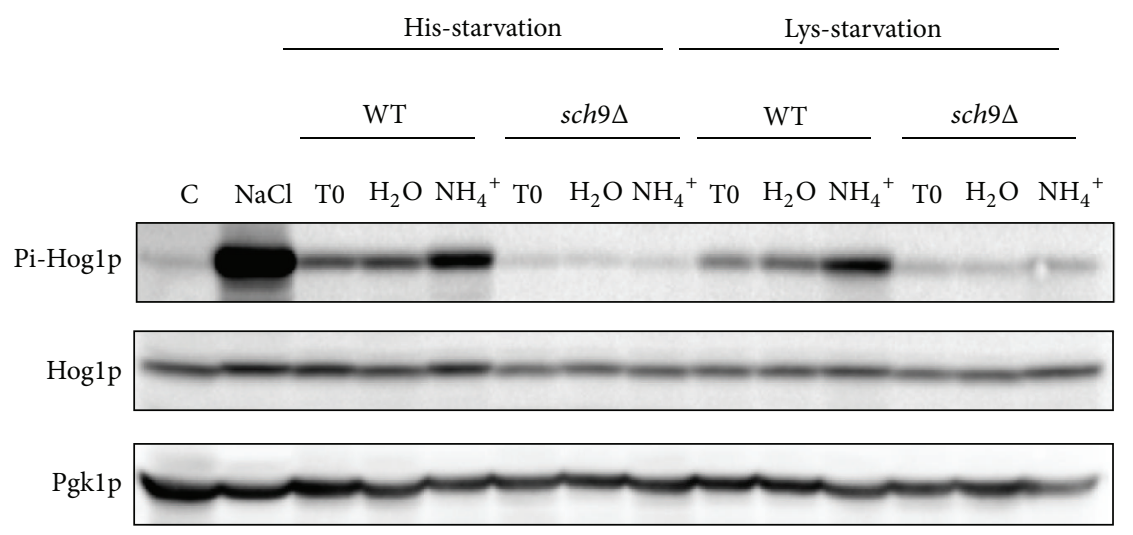

(b)

FIGURE 4: Ammonium induces Sch9p-dependent Hoglp phosphorylation in starvation conditions. Westernblot analysis of Pi-Hoglp levels present in S. cerevisiae (BY4742) wild-type (WT) and sch9s cells starved for (a) all three amino acids or leucine and (b) starved for histidine or lysine, before (T0) and after 20 minutes upon transfer to water $\left(\mathrm{H}_{2} \mathrm{O}\right)$ or water with $\left(\mathrm{NH}_{4}\right)_{2} \mathrm{SO}_{4}, 0.5 \%\left(\mathrm{NH}_{4}{ }^{+}\right)$. In all the cultures, starting cell density was about $3.8 \times 10^{7}$ cells $/ \mathrm{mL}$, and the initial $\mathrm{pH}$ was adjusted to 7.0. Control cells were grown on YPD medium (Control-C) and incubated for 5 minutes in YPD medium supplemented with $1 \mathrm{M} \mathrm{NaCl}$.

leucine has a protective effect on ammonium-induced CLS shortening. The results regarding leucine are in accordance with the literature since it has been described that leucine plays a more important role in CLS extension in auxotrophic strains $[6,10]$. In a recent study, supplementation of extra leucine to SC medium or transformation of auxotrophic leucine strain into a prototrophic leucine strain resulted in CLS extension. The importance of leucine was attributed to the regulation of the branched side chain amino acids synthesis that appears to be misregulated in a leu $2 \Delta$ strain. In agreement, supplemental levels of the branch side amino acids isoleucine, threonine, and valine also extended CLS in a leu2s strain [6]. The negative effect observed for lysine in cell survival during ammonium-induced cell death can possibly be due to the fact that autophagy is inhibited in the presence of ammonium [25], and the lack of autophagy might be responsible for this effect since lysine seems to act in an autophagy-dependent manner on the regulation of CLS. Autophagy-deficient strains showed no improvement in CLS extension after regaining LYS prototrophy in contrast to wildtype autophagy competent cells that increased CLS extension with LYS prototrophy [6].

Both Ras $2 \mathrm{p}$ and Torlp are involved in $\mathrm{NH}_{4}{ }^{+}$-induced CLS shortening in aa-starved cells [25]. We now further established that Ras $2 \mathrm{p}$ involvement on $\mathrm{NH}_{4}{ }^{+}$-induced CLS shortening was present under all conditions tested, and did not depend on starvation. In turn, Torlp function in the decrease of CLS by $\mathrm{NH}_{4}{ }^{+}$was relevant only under amino acid starvation, being differently modulated by the specific amino acid deprived from the medium. Starvation for leucine and histidine, which induced a strong shortening of CLS in the presence of $\mathrm{NH}_{4}{ }^{+}$, had a high impact in the regulation of Torlp function, whereas starvation for lysine, which was associated with only a small $\mathrm{NH}_{4}{ }^{+}$-induced CLS shortening, had a considerably less significant impact on Torlp regulation. These results are in agreement with previous results showing that leucine has an important impact in the regulation of TORC1 $[20,21]$. Our results suggest that the presence of $\mathrm{NH}_{4}{ }^{+}$ in the medium (commonly present as the nitrogen source) may be at least partly responsible for the reported decrease in CLS in leucine-starved cells $[6,14]$.

PKA activation has been described to be associated with the $\mathrm{NH}_{4}{ }^{+}$-induced CLS shortening of aa-starved cells in water [25]. From the results now obtained, and when we compare values from nonstarved and starved wildtype cells, it appears that leucine starvation (alone or in combination with starvation for another amino acid) is the main factor responsible for PKA activation in response to 
$\mathrm{NH}_{4}{ }^{+}$, correlating with its stronger effect on CLS shortening. This activation is dependent on Ras2p, Torlp, and Sch9p, as deficiency in any of these proteins leads to its decrease. However, since the decrease in PKA activation resulted in distinct cell fate outcomes in the different mutants, the results suggest that these proteins activate PKA by independent pathways and/or also regulate other pathways that they do not share and that have different impacts on $\mathrm{NH}_{4}{ }^{+}$-induced CLS shortening. Also, we cannot exclude the possibility that the observed effects on trehalase activity may result from a potential effect of Sch9p, Ras2p, or Torlp on the activity of other proteins also involved in trehalase regulation such as Bmhl/2p or Dcslp [29].

Opposite to our results, Sch9p has been described to inhibit PKA activity when glucose is added to glycerol-grown cells. However, these authors observed that the inhibition was mediated through the regulation of Tpk $2 p$ localization [31], an isoform that does not seem to have a relevant role in response to ammonium under our conditions. In fact, we have previously observed that Tpklp is the main PKA isoform involved in ammonium effects [25]. In addition to its involvement in PKA activation, Sch9p also increases Hoglp phosphorylation, extending CLS in water with or without $\mathrm{NH}_{4}^{+}$.

In summary, herewith we show that the toxic effects of $\mathrm{NH}_{4}{ }^{+}$on CLS shortening are regulated by a starvationdependent and a starvation-independent component and are mediated essentially by Torlp in the first case and by Ras $2 p$ in the second. We also provide evidence that when cells are starved for amino acids, the presence of leucine can ameliorate $\mathrm{NH}_{4}{ }^{+}$-induced CLS shortening, while lysine has the opposite effect, and the presence of histidine has no effect. Together, our data add new knowledge on CLS regulation, indicating that the modulation of nitrogen sources supplied to cells can drastically modulate CLS and providing new clues for the development of environmental interventions for chronological life span extension. Additionally, and since $\mathrm{NH}_{4}{ }^{+}$-induced cell death is involved in different human disorders that are accompanied by hyperammonemia [32], our results, showing that $\mathrm{NH}_{4}{ }^{+}$toxicity can be modulated by amino acids through different pathways, may also afford new insights into the understanding of the cell molecular bases triggering cell death in such pathologies.

\section{Authors' Contribution}

Maria João Sousa and Cecília Leão contributed equally to this work.

\section{Acknowledgment}

This work was supported by FCT, Portugal, Grant PTDC/ AGR-ALI/102608/2008.

\section{References}

[1] J. Santos, C. Leao, and M. J. Sousa, "Growth culture conditions and nutrient signaling modulating yeast chronological longevity," Oxidative Medicine and Cellular Longevity, vol. 2012, Article ID 680304, 10 pages, 2012.

[2] J. V. Gray, G. A. Petsko, G. C. Johnston, D. Ringe, R. A. Singer, and M. Werner-Washburne, "Sleeping beauty": quiescence in Saccharomyces cerevisiae," Microbiology and Molecular Biology Reviews, vol. 68, no. 2, pp. 187-206, 2004.

[3] M. Rubio-Texeira, G. Van Zeebroeck, K. Voordeckers, and J. M. Thevelein, "Saccharomyces cerevisiae plasma membrane nutrient sensors and their role in PKA signaling," FEMS Yeast Research, vol. 10, no. 2, pp. 134-149, 2010.

[4] V. D. Longo, E. B. Gralla, and J. S. Valentine, "Superoxide dismutase activity is essential for stationary phase survival in Saccharomyces cerevisiae: mitochondrial production of toxic oxygen species in vivo," Journal of Biological Chemistry, vol. 271, no. 21, pp. 12275-12280, 1996.

[5] P. Fabrizio and V. D. Longo, "The chronological life span of Saccharomyces cerevisiae," Aging Cell, vol. 2, no. 2, pp. 73-81, 2003.

[6] A. L. Alvers, L. K. Fishwick, M. S. Wood et al., "Autophagy and amino acid homeostasis are required for chronological longevity in Saccharomyces cerevisiae," Aging Cell, vol. 8, no. 4, pp. 353-369, 2009.

[7] P. Gomes, B. Sampaio-Marques, P. Ludovico, F. Rodrigues, and C. Leão, "Low auxotrophy-complementing amino acid concentrations reduce yeast chronological life span," Mechanisms of Ageing and Development, vol. 128, no. 5-6, pp. 383-391, 2007.

[8] C. J. Murakami, C. R. Burtner, B. K. Kennedy, and M. Kaeberlein, "A method for high-throughput quantitative analysis of yeast chronological life span," Journals of Gerontology A, vol. 63, no. 2, pp. 113-121, 2008.

[9] D. L. Smith Jr., J. M. McClure, M. Matecic, and J. S. Smith, "Calorie restriction extends the chronological lifespan of Saccharomyces cerevisiae independently of the Sirtuins," Aging Cell, vol. 6, no. 5, pp. 649-662, 2007.

[10] V. M. Boer, S. Amini, and D. Botstein, "Influence of genotype and nutrition on survival and metabolism of starving yeast," Proceedings of the National Academy of Sciences of the United States of America, vol. 105, no. 19, pp. 6930-6935, 2008.

[11] J. C. Jiang, E. Jaruga, M. V. Repnevskaya, and S. M. Jazwinski, "An intervention resembling caloric restriction prolongs life span and retards aging in yeast," FASEB Journal, vol. 14, no. 14, pp. 2135-2137, 2000.

[12] S.-J. Lin, P.-A. Defossez, and L. Guarente, "Requirement of NAD and SIR2 for life-span extension by calorie restriction in Saccharomyces cerevisiae," Science, vol. 289, no. 5487, pp. 2126$2128,2000$.

[13] R. W. Powers III, M. Kaeberlein, S. D. Caldwell, B. K. Kennedy, and S. Fields, "Extension of chronological life span in yeast by decreased TOR pathway signaling," Genes and Development, vol. 20, no. 2, pp. 174-184, 2006.

[14] J. P. Aris, A. L. Alvers, R. A. Ferraiuolo et al., "Autophagy and leucine promote chronological longevity and respiration proficiency during calorie restriction in yeast," Experimental Gerontology, 2013.

[15] R. Loewith and M. N. Hall, "Target of rapamycin (TOR) in nutrient signaling and growth control," Genetics, vol. 189, no. 4, pp. 1177-1201, 2011.

[16] B. Smets, R. Ghillebert, P. De Snijder et al., "Life in the midst of scarcity: adaptations to nutrient availability in Saccharomyces cerevisiae," Current Genetics, vol. 56, no. 1, pp. 1-32, 2010. 
[17] J. L. Crespo and M. N. Hall, "Elucidating TOR signaling and rapamycin action: lessons from Saccharomyces cerevisiae," Microbiology and Molecular Biology Reviews, vol. 66, no. 4, pp. 579-591, 2002.

[18] C. De Virgilio and R. Loewith, “The TOR signalling network from yeast to man," International Journal of Biochemistry and Cell Biology, vol. 38, no. 9, pp. 1476-1481, 2006.

[19] J. Avruch, X. Long, S. Ortiz-Vega, J. Rapley, A. Papageorgiou, and N. Dai, "Amino acid regulation of TOR complex 1," American Journal of Physiology. Endocrinology and Metabolism, vol. 296, no. 4, pp. E592-E602, 2009.

[20] M. Binda, M.-P. Péli-Gulli, G. Bonfils et al., "The Vam6 GEF controls TORC1 by activating the EGO complex," Molecular Cell, vol. 35, no. 5, pp. 563-573, 2009.

[21] G. Bonfils, M. Jaquenoud, S. Bontron, C. Ostrowicz, C. Ungermann, and C. De Virgilio, "Leucyl-tRNA synthetase controls TORC1 via the EGO complex," Molecular Cell, vol. 46, no. 1, pp. 105-110, 2012.

[22] J. M. Thevelein, L. Cauwenberg, S. Colombo et al., "Nutrientinduced signal transduction through the protein kinase A pathway and its role in the control of metabolism, stress resistance, and growth in yeast," Enzyme and Microbial Technology, vol. 26, no. 9-10, pp. 819-825, 2000.

[23] B. Smets, P. De Snijder, K. Engelen et al., "Genome-wide expression analysis reveals TORC1-dependent and -independent functions of Sch9," FEMS Yeast Research, vol. 8, no. 8, pp. 12761288, 2008.

[24] M. Crauwels, M. C. V. Donaton, M. B. Pernambuco, J. Winderickx, J. H. De Winde, and J. M. Thevelein, "The Sch9 protein kinase in the yeast Saccharomyces cerevisiae controls cAPK activity and is required for nitrogen activation of the fermentable-growth-medium-induced (FGM) pathway," Microbiology, vol. 143, no. 8, pp. 2627-2637, 1997.

[25] J. Santos, M. J. Sousa, and C. Leao, "Ammonium is toxic for aging yeast cells, inducing death and shortening of the chronological lifespan," PLoS One, vol. 7, Article ID e37090, 2012.

[26] O. Braissant, "Current concepts in the pathogenesis of urea cycle disorders," Molecular Genetics and Metabolism, vol. 100, supplement 1, pp. S3-S12, 2010.

[27] M. B. Pernambuco, J. Winderickx, M. Crauwels, G. Griffioen, W. H. Mager, and J. M. Thevelein, "Glucose-triggered signalling in Saccharomyces cerevisiae: different requirements for sugar phosphorylation between cells grown on glucose and those grown on non-fermentable carbon sources," Microbiology, vol. 142, part 7, pp. 1775-1782, 1996.

[28] N. Camougrand, I. Kissová, B. Salin, and R. J. Devenish, "Monitoring mitophagy in yeast," Methods in enzymology, vol. 451, pp. 89-107, 2008.

[29] W. Schepers, G. Van Zeebroeck, M. Pinkse, P. Verhaert, and J. M. Thevelein, "In vivo phosphorylation of Ser21 and Ser83 during nutrient-induced activation of the yeast protein kinase A, (PKA) target trehalase," The Journal of Biological Chemistry, vol. 287, pp. 44130-44142, 2012.

[30] A. Pascual-Ahuir and M. Proft, "The Sch9 kinase is a chromatinassociated transcriptional activator of osmostress-responsive genes," EMBO Journal, vol. 26, no. 13, pp. 3098-3108, 2007.
[31] A. Zhang, Y. Shen, W. Gao, and J. Dong, "Role of Sch9 in regulating Ras-cAMP signal pathway in Saccharomyces cerevisiae," FEBS Letters, vol. 585, no. 19, pp. 3026-3032, 2011.

[32] M. D. Norenberg, K. V. R. Rao, and A. R. Jayakumar, "Signaling factors in the mechanism of ammonia neurotoxicity," Metabolic Brain Disease, vol. 24, no. 1, pp. 103-117, 2009. 


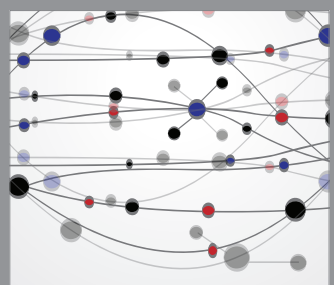

The Scientific World Journal
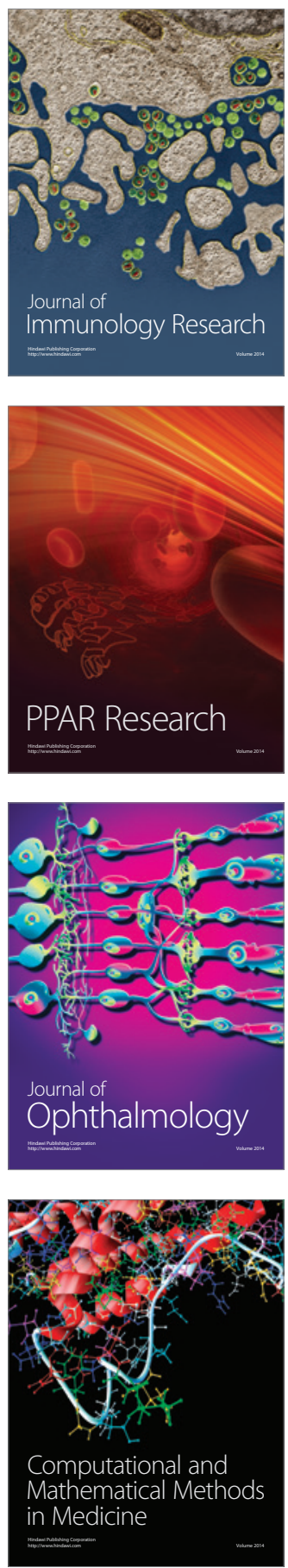

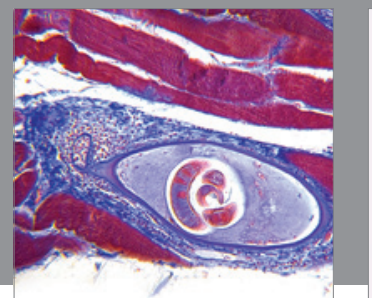

Gastroenterology

Research and Practice
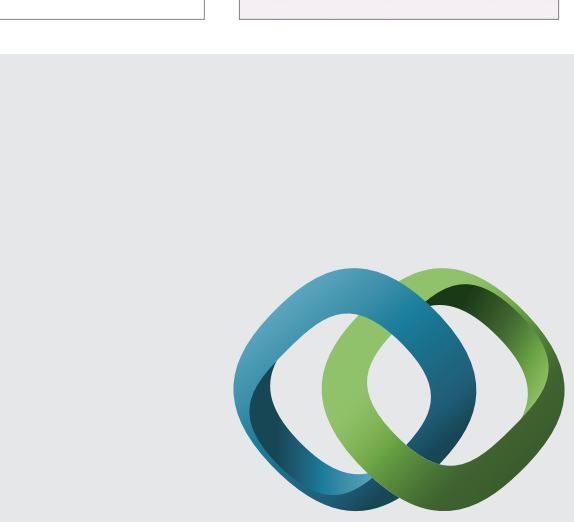

\section{Hindawi}

Submit your manuscripts at

http://www.hindawi.com
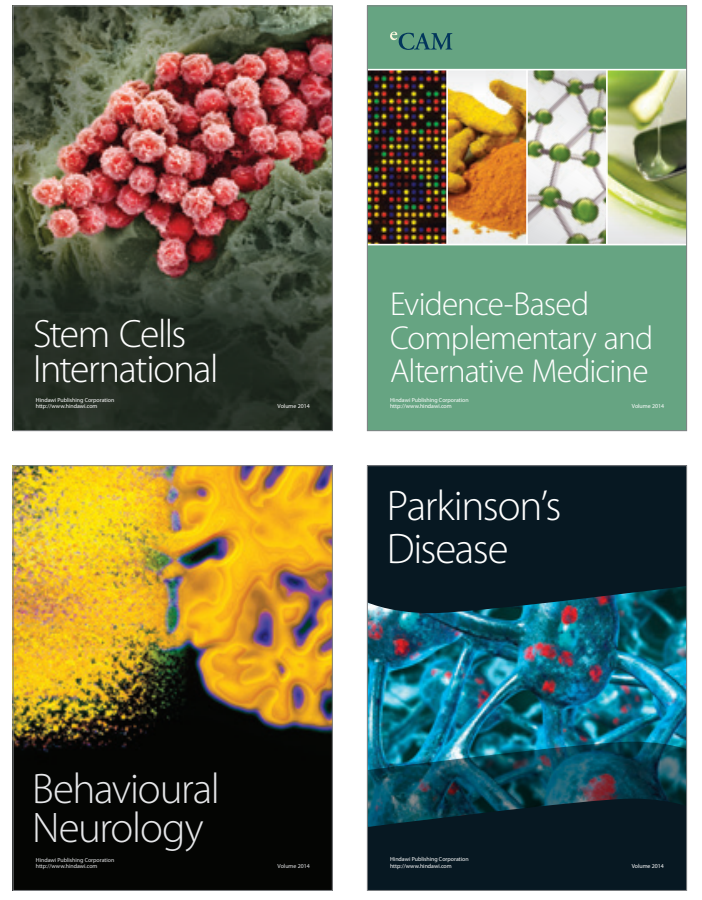
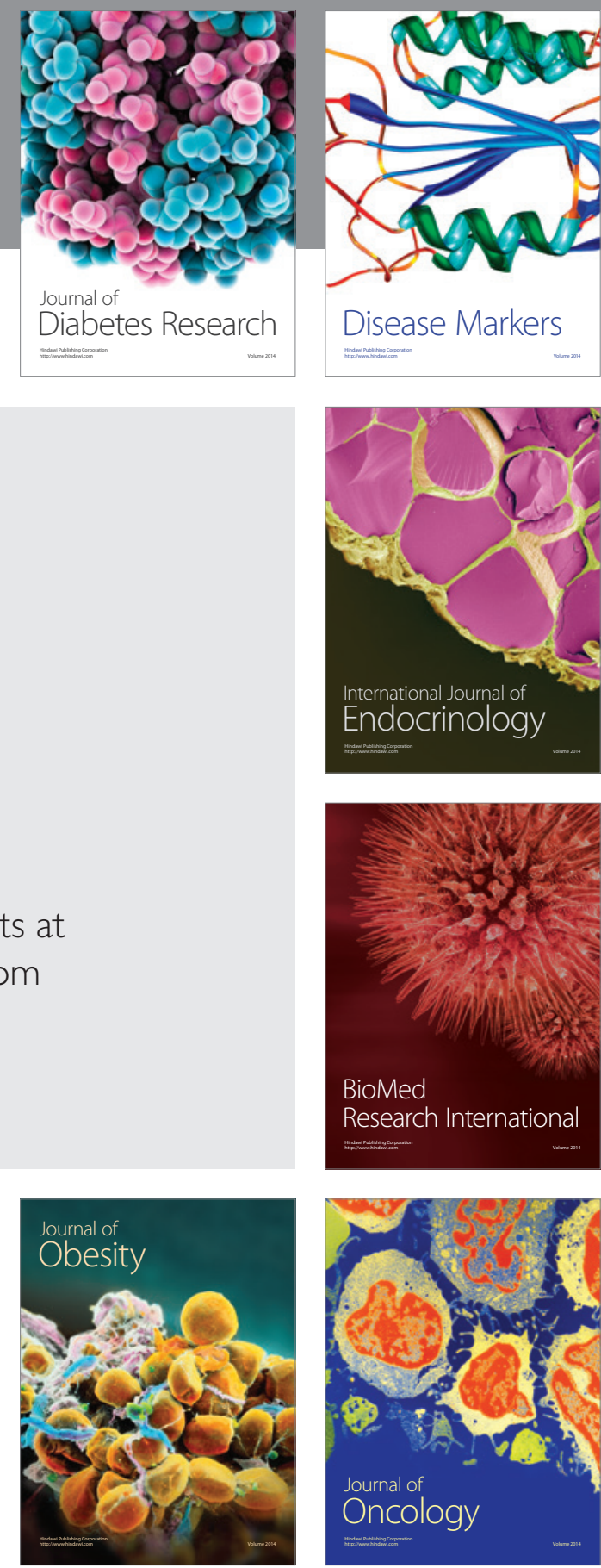

Disease Markers
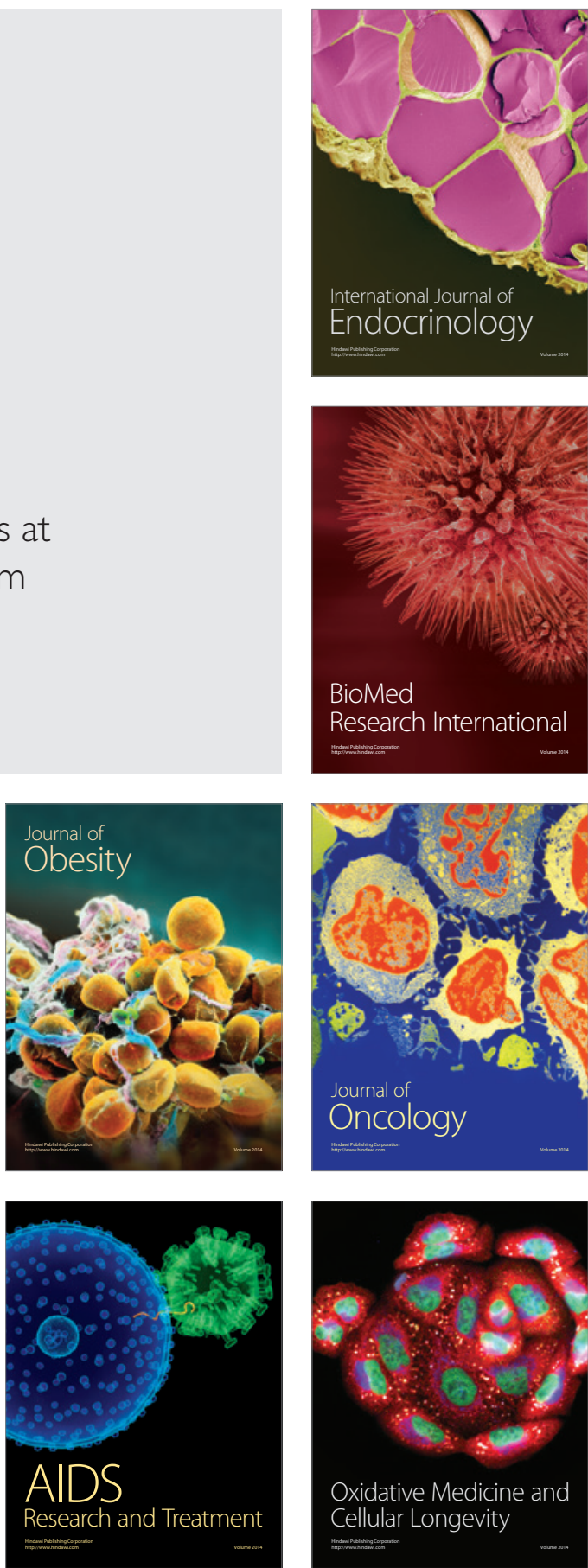